Zouari, G., \& Abdelmalek, I. (2020). Financial innovation, risk management, and bank performance. Copernican Journal of Finance \& Accounting, 9(1), 77-100. http://dx.doi.org/10.12775/ CJFA.2020.004

\author{
GHAZI ZOUARI* \\ University of Sfax
}

Imen Abdelmalek**

University of Sfax

\title{
FINANCIAL INNOVATION, RISK MANAGEMENT, AND BANK PERFORMANCE
}

Keywords: financial innovation, risk management, performance of Tunisian banks.

J E L Classification: G21, G32, 030.

Abstract: Several researches conducted from the angle of corporate governance reveals that the majority of the work that examines the direct association between financial innovation and bank performance has displayed mixed results and has ignored the indirect relationship between these two variables through the risk management of incurred by the bank. In this context, the purpose of this study is to investigate whether or not there is a mediating effect of risk management on the relationship between financial innovation and bank performance. Data collected from annual activity reports of banks listed on the Tunis Stock Exchange is analyzed, and used to validate the theoretical and empirical contributions of our article. The empirical study uses the Panel data extracted from 10 banks, over the period ranging from 2009 to 2017, and the Baron and

Date of submission: March 10, 2020; date of acceptance: April 24, 2020.

* Contact information: ghazi.zouari@fsegs.usf.tn, Faculty of Economic Sciences and Management, University of Sfax, Airport Road, km 4.5, PB: 1088, Sfax 3018, Tunisia, phone: +216 22633 500; ORCID ID: https://orcid.org/0000-0002-8168-3266.

${ }^{* *}$ Contact information: imenabdelmalek@fsegs.u-sfax.tn, Faculty of Economic Sciences and Management, University of Sfax, Airport Road, km 4.5, PB: 1088, Sfax 3018, Tunisia, phone: +216 28461 817; ORCID ID: https://orcid.org/0000-0003-2453-6312. 
Kenny (1986) mediation approach has been estimated, using specifications of random effects. Our empirical analysis substantiates that financial innovation has a positive direct effect on stock market performance, and a non-significative impact on financial profitability. Additionally, our results show that improving the stock market performance of banks by financial innovation depends on the mediator role of the operational risk management. To remain improving performance, Tunisian banks must pay more attention on special training of bank managers whose function relate to the choice of financial innovations and manage the associated risks.

\section{INTRODUCTION}

In literature review, the concept of financial innovation is so broad, and evolves over time. It is defined in different ways (Merton, 1992; Tufano, 2003; Frame \& White, 2002; Llewellyn, 2009; Sokołowska, 2014). According to Tufano (2003), "financial innovation is the act of creating and then popularizing new financial instruments as well as new financial technologies, institutions and markets". Financial innovation is a process, carried out by any institution, involving the creation, promotion and adoption of new (including both incremental and radical) products, platforms and processes. It is also a technology catalyst introducing new ways of or changes in conducting a financial activity (Khraisha \& Arthur, 2018; Sokołowska, 2014). We act in accordance with Nejad's (2016) concept of financial innovation, consisting in "the development, introduction, and management of a product, service, a business model, or a process that is developed to directly serve the financial industry".

The development of financial innovation contributes to the wealth of shareholders. However, the crisis that affected global financial stability and the economy in 2007/2008, the financial innovation has become risky (Arthur, 2017), and a source of bank fragility (Beck, Chen, Lin \& Song, 2016). Researchers have revealed that the leading cause of crisis is the lack of how to govern innovation, specifically the management risk of innovation. Consequently, the crisis has reinforced the need to rethink some of the approaches adopted by the financial community in assessing bank performance. To this end, it is important to obtain a comprehensive view of the key factors that may influence banks' performance, including the adequacy of financial innovations choices in relation to risk management, and the question of how this adequacy is handled through banking governance. 
Like the innovation in the industrial sector, the financial innovation is characterized by high risk, costly investment, specific asset to the firm, and longhorizon return (Zouari \& Zouari-Hadiji, 2014a; 2014b). These characteristics represent the factors bringing about agency conflicts between shareholders and stakeholders, on the one hand, and the opportunistic behavior of managers for the purpose of maximizing their wealth at the expense of stakeholders, on the other hand. According to the agency theory, managers are risk averse and innovation activity (Minetti, Murro \& Paiella, 2015) whereas the shareholders facilitate the innovation activity in order to increase company stability, and to generate value (Asensio-López, Cabeza-García \& González-Álvarez, 2019). Owing to the interest conflict and information asymmetry problems between managers, shareholders and stakeholders, managers will be encouraged to take advantage of an opportunistic behavior. Thereby, the manager's behavior toward risk and corporate governance can affect the choice of innovation and risk management activities.

Moreover, depending on the transaction cost theory, Williamson (1985) advocates that investing in specialized assets increases the transaction costs via providing concerns about exchange problems such as potential bargaining and opportunism. Thus, innovations spur on risk-taking, generating costs. Hence, risk management is necessary to reduce these costs and control risks.

For the reasons mentioned above, our study aims to scrutinize the effect of financial innovation on risk management and bank performance.

The rest of the paper is structured as follows. The next section deals with a literature review and hypothesis development. The subsequent section covers the methodology while the fourth one presents the analyses. The fifth section is about results and discussions, and the last one concludes, presents the limitations, and outlines possible future research.

\section{RELATED LITERATURE AND HYPOTHESIS DEVELOPMENT}

\section{The research methodology and the course of the research process}

A conceptual model for this study is indicated in figure 1. Our research asserts that financial innovation will have an influence on bank performance. The risk management is shown as a prominent mediator between financial innovation and bank performance. 


\section{Financial innovation and bank performance}

The financial innovation allows banks to create a competitive advantage through cost reduction with the aim of improving their financial performance via mitigating risk. Innovation is so substantial that it contributes to the economic growth and stability of financial system (Lerner \& Tufano, 2011). Specifically, banks improve their quality, and enhance their performance by developing a financial innovation. For instance, they innovate new forms of financial securities, new forms of mortgage lending, new means of processing transactions, or new organizational forms such as Internet banks. Studying the diffusion of financial innovation has been linked to the speed and pattern. The diffusion of financial innovation is of great value for ensuring corporate return on investment from innovation (Khraisha \& Arthur, 2018). De Young, Lang and Nolle (2007) suggest that Internet adoption makes the profitability of American community banks better. Ciciretti, Hasanand and Zazzara (2009) provide evidence of a significant link between Internet banking service and bank performance. In addition, Mabrouk and Mamoghli (2010) point out that the primary mover of product innovation improves the bank profitability, and the primary mover in process innovation has a positive effect on bank profitability and efficiency. Mabrouk, Dhouibi and Rouetbi (2016) conclude that financial innovation is a value creation instrument for Tunisian banks. Several studies demonstrate as well that bank performance increase after the adoption of innovation (Mustapha, 2018; Chipeta \& Muthinja, 2018; Lotto, 2019). Hence, this study hypothesizes the following:

H1. The financial innovation has a positive impact on the bank performance.

\section{Financial innovation and risk management}

Financial innovation is associated with risks (Baiquan \& Kebao, 2010) leading to bank fragility (Beck et al., 2016). These risks include market risk, credit risk and operational risk (Baiquan \& Kebao, 2010). Investment in financial innovation reinforces the financial risk management. The risk management is an essential part of the innovation lifecycle, and it helps address ambiguity and uncertainty. However, a few empirical studies have tested the relationship of financial innovation and risk management (Hu, Li \& Deng, 2009; Baiquan \& Ke- 
bao, 2010; González, Rodríguez Gil, Cunill \& Lindahl, 2016). Philippas and Siriopoulos (2009) analyze the relationship between financial innovation (process / organizational) and operational risk. Their results indicate that the speed of diffusion of financial innovation increases operational risk. González et al. (2016) add that securitization increases the overall default risk of European financial institutions. The results for study of Zia, Muhammad, Sarwar and Asif Raz (2019) identified four areas of impact on credit risk management: corporate governance exerts the greatest impact, followed by diversification or innovation, which plays a significant role, hedging and, finally, the bank's Capital Adequacy Ratio. This study highlights these four risk management strategies, which are critical for commercial banks to resolve their credit risk. Mabrouk et al. (2016) show that there is a significant direct effect of each innovation type (process / product) on credit risk, adopting that product innovation has increased the volume of non-performing loans of Tunisian Banks. Therefore, we posit the hypothesis as follows:

H2. The financial innovation has a positive impact on the risk management.

\section{Risk management and bank performance}

The traditional role of banking intermediation is changing as the bank is operating in an uncertain financial environment. Risk management becomes a relevant function reducing the costs and preventing distortions in investment policy (Stulz, 2016; Ellul, 2015).

"The risk management as an active, strategic, and integrated process that encompasses both the measurement and the mitigation of risk, with the ultimate goal of maximizing the value of a bank" (COSO, 2004). In the institutional theory framework, Stulz and Smith (1985) are the first introducing the relevant role of risk management at the firm, enhancing the firm value under inefficiency of market conditions. The risk management decreases the agency cost of equity or debt, and cost transaction. Additionally, the bank uses the risk management to reduce the cost of financial distress by decreasing the default probability, and to increase the value of firms and shareholders.

In the empirical studies, the relationship between risk management and bank performance is not usually positive. This is related to different determinants like country of studies. In fact, the risk management reduces the cost, 
but does not guarantee increase in the return on equity (Olamide, Uwalomwa \& Ranti, 2015; Mendoza \& Rivera, 2017). In recent studies, Zgarni and Hassouna (2018) have perceived that prudential rules measured by the solvency ratio and liquidity ratio improve the accounting performance of Tunisian banks. On the other hand, recent empirical contributions have given proof that the bank with Chief Risk Officer (CRO) maintains a positive relationship with bank performance and the value of shareholders (McShane, Nair \& Rustambekov, 2011; Battaglia, Fiordelisi \& Ricci, 2017). In the same context, Fatemi and Fooladi (2006) note that effective risk management leads to more balanced trade-off between risk and reward, to realize a better position in the future. The studies of Hosna, Manzura and Juanjuan (2009), Toutou and Xiaodong (2011) and Zeze (2012) found that have a positive correlation between the financial risk management practices to the financial performance of commercial banks.

In this respect, Wanjohi, Wanjohi and Ndambiri (2017) have discovered that an efficient risk management can help banks attenuate their exposure to risk and enhance their market competitiveness. Moreover, the study on Malaysian banks by Trofimov, Aris and Ying Ying (2018) also shows that the continuing need to manage credit risk is among the most important factors that explain high bank profitability. For Paroush and Schreiber (2019), there are significant relationship between profitability, capital, and risk of US commercial. Furthermore, Lotto (2019) revealed that capital adequacy has a positive relationship with bank operating efficiency, and reduce the risk of moral hazard between shareholders and dets-holders.

Findings of Kiambati (2020) and Sathyamoorthi, Mogotsinyana, Mphoeng and Mashoko (2020) suggest that commercial banks should strike a proper balance between financial risk management practices and financial performance by engaging in appropriate market, credit, and liquidity risk management practices that will ensure safety for their banks and yield positive profits. Consequently, we present the following hypothesis:

H3. The risk management has a positive impact on the bank performance. 


\section{The risk management as a mediator between financial innovation and bank performance}

The risk management is defined from different angles as institutional, regulatory or functional. From the regulatory angle, the risk management is determined by the prudential rules defined by the Basel Committee. We will focus on Basel II/III agreements approved by Tunisian banks. The complexity and dynamic of financial innovation have raised an uncertain environment. This uncertainty is at the origin of the bank's lack of understanding of the new financial products, obsolete regulations and excessive risk-taking.

Several research studies show that the financial innovation is associated with high risk and contributed to the fragility of banks. According to the study of Philippas and Siriopoulos (2009), the diffusion of financial innovation raises the operational risk. Hu and Xie (2016) evince that innovation positively affects bank risk-taking. In line with these ideas, Wang (2014) argues that the financial innovation decreases the bank value. Similarly, Chen and Peng (2019) argue that financial innovation increase banks' liquidity risk. They conclude that banks should ensure an appropriate management of financial innovation to improve their performance.

In other words, the bank should monitor these risks correlated with the conflicts of interest between shareholders and stakeholders, and the opportunistic behavior of agents that could generate agency and transaction costs, and information asymmetry. These costs influence the profitability of the shareholders as well as the firm value, especially in the short term and in the long run, without managing the internal and external risks throughout the innovation process.

In the governance framework, the financial institutions use risk management processes so as to minimize costs and control risks. The risk management allows to reduce the cost of investment innovation incurred due to agency conflict. Some studies have tested the mediating effect of risk management on the relationship between innovation and project management in non-financial companies (Jordan, Jorgensen \& Mitterhoferh, 2013). However, Guermazi (2017) has studied the mediating role of risk management in financial corporations, and has realised that the improvement in insurance and bank quality throughout innovation depends on the mediating role of risk management. 
In our paper, we will look for the existence of a mediating effect of risk management between innovation and the bank performance. Accordingly, we deduce the following hypothesis:

H4. Risk management mediates the relationship between financial innovation and bank performance.

Figure 1. Research Model

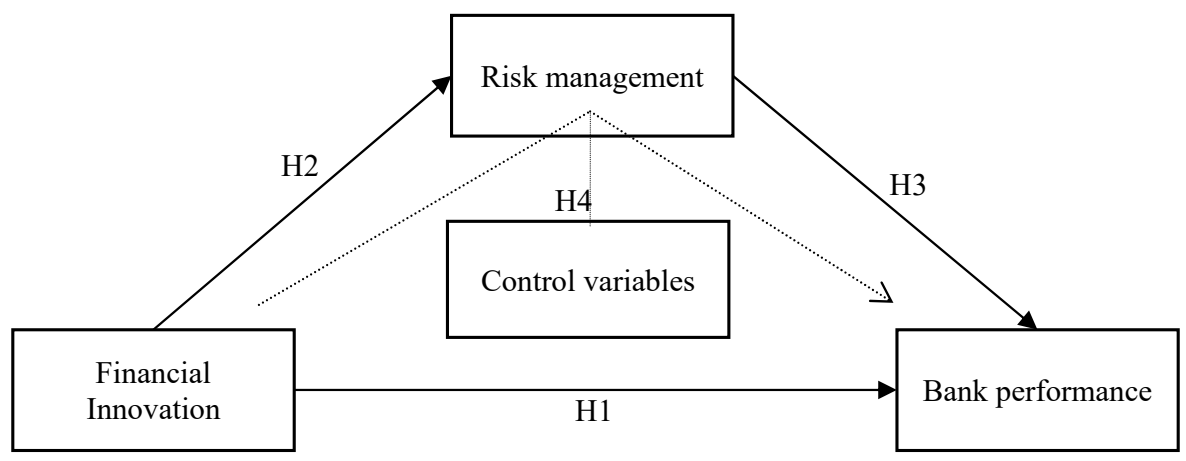

S o u r c e : author's modeling, 2019.

\section{RESEARCH METHODOLOGY}

This section aims to test the impact of the characteristics of financial innovation on the bank performance. This effect is mediated by risk management. To do this, we will present our sample, the response and explanatory variables, and the regression analysis.

\section{Presentation of data and variable measurements}

The data is collected from 10 Tunisian listed commercial banks ${ }^{1}$ listed on the Tunis Stock Exchange. All the relevant data is obtained from the bank annu-

1 ATB: Arab Tunisian Bank, BIAT: Banque Internationale Arabe de Tunisie, AB: Amen Bank, UBCI: Union Bancaire pour le Commerce et l'Industrie, ATTIJARI: Attijari Bank, UIB: Union Internationale de Banque, BT: Banque de Tunisie, BNA: Banque Nationale Agricole, STB: Société Tunisienne de Banque, BH: Banque de l’Habitat. 
al reports, and reference documents of Financial Market Council in the period spanning from 2009 through 2017. Our choice of this period is based on the availability of data and it represents a post-financial crisis period from $2007 / 2008$ so as not to bias the results by the effect of this crisis on banking performance. In sum, the total number of Tunisian banks selected for statistical testing amounts to 10 banks, making up a total number of observations equal to 90 .

\section{Dependent variables}

According to the European Central Bank (ECB, 2010), the bank performance is defined as the "capacity to generate sustainable profitability". Therefore, and as in previous studies, we use two measures of bank performance. Following Mabrouk and Mamoghli (2010), Zouari and Zouari-Hadiji (2014a; 2014b) ${ }^{2}$ and Wanjohi et al. (2017), the first one is the return on equity as a traditional measure of performance, reflecting the ability of a bank to generate profits through investment (Return On Assets "ROE" = operating income before depreciation and R\&D / total equity). The second one is the market to book value as marketbased measures of performance, relating the market value of stockholders' equity to its book value (Market to Book "MTB" = market capitalization / book value of equity).

\section{Independent variables}

Through empirical studies, financial innovation is assessed, using two different types of input and output ratios (Stone, Shipp \& Leader, 2008), and it is measured by three different ways. The first measurement indicator is the innovation index (Heffernan, Fu \& Fu, 2008) that has been converted into percentages to facilitate exposure, and can vary from $0 \%$ to $100 \%$. The second measurement indicator is banking channels such as ATM's, mobile payment, call center, mobile banking, Internet banking, POS (point of sale) terminals and branch (De Young, Lang \& Nolle, 2007; Ciciretti, Hasanand \& Zazzara, 2009;

2 This measurement of the accounting performance has the advantage of eliminating the effect of accounting choices related to the treatment of $R \& D$ in the financial statements largely subject to the opportunism of managers. 
Usman, 2016; Tunay, Tunay \& Akhisar, 2015). The last measurement one is the financial R\&D intensity (value added) and the financial R\&D intensity (cost) (Beck et al., 2016).

Based on indicators of Oslo Manuel via the OECD/Eurostat (2005), we use input ratios for the purpose of measuring the financial innovation, reflecting the acquisition of capital goods related to innovation activities. These activities include, on the one hand, the acquisition of external knowledge and technology (patents, licenses, software, trademarks...) and, on the other hand, the acquisition of machinery, equipment, and other capital goods. FinInn is the ratio of the sum of tangible and intangible assets related to innovation to total assets (OECD, 2005; Beck et al., 2016).

\section{Mediating variable}

The stability of the bank is linked to an effective risk management through applying regulatory conditions (Halim, Mustika, Sari, Anugerah \& Mohd-Sanusi, 2017). Risk management is assessed in two different ways: prudential and operational. We use the prudential proxy on the basis of the measure applied on the second Basel Accords by Basel Committee (El Attar \& Atmani, 2015). We take on capital adequacy ratio (CAR), credit risk-weighted asset ratio (CRW) and operational risk-weighted asset ratio (ORW) so that we can measure the bank risk management.

CAR is a measure of the amount of bank's core capital expressed as a percentage of its risk-weighted asset, determining the bank's capacity to meet liabilities and other risks such as credit and operational risks. CRW is the ratio of credit risk-weighted asset to total risk-weighted asset. ORW is the ratio of operational risk-weighted asset to total risk-weighted asset.

\section{Control variables}

Control variables are specific to banks which are: non-performing loans (NPLS) as the ratio of non-performing loans to total loans, liquidity coverage ratio (LCR) as liquid assets to liquid liabilities, operational efficiency (OE) as the ratio of operating incomes to operating expenses (Malhotra \& Singh, 2009; Arnaboldi \& Rossignoli, 2015; Piyananda, Chandrasena \& Fernando, 2015). 


\section{Regression model specifications}

The empirical study, as undertaken in our work, is based on using hierarchical regression models ${ }^{3}$ for the purpose of testing the research of advanced hypotheses. For the assumptions made to be assessed via a procedure achievable through the construction of four models, it seems necessary to test the existence of a mediating effect. Baron and Kenny (1986) consider four conditions for a complete mediating effect to be checked in terms of CAR, CRW, ORW of the FinInn- ROA, MTB relationship. These conditions are the following:

(1) The independent variable (FinInn) has a significant impact on the bank performance (ROA, MTB).

(2) The FinInn significantly influences the mediator variable (CAR, CRW, ORW).

(3) When the influence of CAR, CRW, ORW on the bank performance is taken into account, the FinInn will have no significant effect on performance.

(4) The direct effect of FinInn on performance should be null, or reduced by the insertion of the mediator variable in order to deduce its mediating impact within the relationship.

Econometrically, we first estimate Model 1 with the aim of testing the direct effect of FinInn on bank performance (ROA, MTB), and validating hypothesis (H1).

${ }^{3}$ In this work, the treatment of mediating variables should follow the approach devised by Baron and Kenny (1986). This framework, which aims at testing the mediating effect, is implemented via a multiple-hierarchical regression. This analysis consists in assessing the total effect (cumulative) of the explanatory variables on a certain criterion. The method can be performed on the basis of several steps. Firstly, it undertakes to test the predictor effect (independent variable) firstly on the criterion (dependent variable), and secondly on the mediator using partial and simple regressions. Then, the other relationship has to be tested (predictor and mediator on the criterion). In this case, a multiple-hierarchical regression has to be applied. It consists in gradually introducing certain independent variables into the regression equation: starting with the predictor and control variables (Step 1), and then the mediating variable (Step 2). Upon reaching an increase in the adjusted $\mathrm{R}^{2}$ after inserting the mediator, it will be possible to assume the mediator effect on the relationship between the predictor and the criterion, Zouari and Zouari-Hadiji (2014a; 2014b). 


$$
P_{i t}=\alpha+\beta_{i 1} \text { FinInn }_{i t}+\delta_{1} Z_{i t}+\varepsilon_{i t}
$$

Second, we estimate the relationship between FinInn and risk management (CAR, CRW, ORW) so as to validate hypothesis (H2)

$$
R M_{i t}=\alpha+\beta_{i 1} \text { FinInn }_{i t}+\delta_{1} Z_{i t}+\varepsilon_{i t}
$$

Afterwards, we estimate the relationship between risk management (CAR, CRW, ORW) and bank performance (ROA, MTB) for validating hypothesis (H3)

$$
P_{i t}=\alpha+\beta_{i 1} R M_{i t}+\delta_{1} Z_{i t}+\varepsilon_{i t}
$$

Eventually, we examine the indirect relationship between FinInn and bank performance (ROE, MTB), using the effect of risk management (CAR, CRW, ORW)

$$
P_{i t}=\alpha+\beta_{i 1} \text { FinInn }_{i t}+\gamma_{i 1} R M_{i t}+\delta_{1} Z_{i t}+\varepsilon_{i t}(H 4)
$$

$\mathrm{P}_{\mathrm{it}}=$ Bank performance measured by $\mathrm{ROA}_{\mathrm{it}}$ and $\mathrm{MTB}_{\mathrm{it}}$ ratios

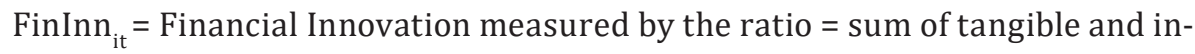
tangible asset ${ }_{i t}$ / innovation to total asset ${ }_{i t}$ )

$\mathrm{RM}_{\mathrm{it}}=$ Risk management measured by $\mathrm{CAR}_{\mathrm{it}}, \mathrm{CRW}_{\mathrm{it}}$ and $\mathrm{ORW}_{\mathrm{it}}$ $\mathrm{Z}_{\mathrm{it}}=$ Control variables measured by NPL $\mathrm{L}_{\mathrm{it}} \mathrm{LCR}_{\mathrm{it}}$ and $\mathrm{OE}_{\mathrm{it}}$

- $\beta, \gamma$ and $\alpha$ : Parameters to be estimated

- $\varepsilon_{1}$ : The random error

\section{ANALYSES}

In order to test the hypothetical relationships, our research has followed the commonly established two-stage procedure. The first stage is the descriptive statistics and correlation results. Indeed, the normality of the variables is supposed to be checked because the number of observations is greater than 30 . 
According to the Pearson correlation, as shown in table 1, there are no correlations exceeding 0.5 between our explanatory variables, which means the absence of multi-collinearity problems between the independent variables.

Table 1. Descriptive statistics and Pearson correlation matrix

\begin{tabular}{|l|c|c|c|c|c|c|c|c|c|}
\hline \hline & Mean & (s.d) & $\mathbf{1}$ & $\mathbf{2}$ & $\mathbf{3}$ & $\mathbf{4}$ & $\mathbf{5}$ & $\mathbf{6}$ & $\mathbf{7}$ \\
\hline \hline ROE & 0.12 & 0.11 & - & - & - & - & - & - & - \\
\hline MTB & 1.51 & 0.97 & - & - & - & - & - & - & - \\
\hline 1 FinInn & 0.09 & 0.11 & 1 & & & & & & \\
\hline 2 CAR & 0.11 & 0.03 & -0.103 & 1 & & & & & \\
\hline 3 CRW & 0.89 & 0.11 & 0.032 & -0.0003 & 1 & & & & \\
\hline 4 ORW & 0.09 & 0.02 & 0.1427 & 0.151 & -0.184 & 1 & & & \\
\hline 5 NPL & 0.13 & 0.09 & -0.196 & -0.221 & 0.025 & -0.463 & 1 & & 1 \\
\hline 6 LCR & 1.08 & 0.43 & -0.0111 & 0.184 & 0.020 & 0.284 & -0.119 & 1 & \\
\hline 7 OE & 3.28 & 5.17 & -0.122 & -0.249 & -0.018 & -0.291 & 0.291 & -0.167 & 1 \\
\hline \hline
\end{tabular}

N o t e : aStandard deviation. All correlations between variables are significantly smaller than 0.6 (threshold at which we begin to experience serious problems of multi-colinearity). In the Pearson test and the index of conditioning, we have found that these variables are distinct from each other and are not significant (correlation thresholds are above 10\%, and the packaging is less than 1000).

S o u r c e : author's computation, 2019.

In the second stage, the relationship between the variables are analysed by using Panel data, following the method of Baron and Kenny (1986). To start with, the test of homogeneity is conducted to validate the existence of individual effects in models. Referring to table 2 , the results show that the p-values associated with the F-statistic calculated for each model are less than $1 \%$ and $10 \%$, except for models 4 and 10 which do not require specific effects. These two models will be estimated with pooled OLS regression.

The second specification test determines the nature of the specific effects to be either of random or fixed type. The Hausman test is the most appropriate one to specify the preferred model. The null hypotheses of models 2 and 11 which are rejected ( $p$-values $<1 \%$ ) are estimated by the fixed effects. Given these results, the final model to be estimated will be a heterogeneous panel of random effects for 1,3,5,6,7,8,9 models. 
Aiming to achieve better results, we need to check the problem of heteroscedasticity and autocorrelation of errors. The Breush-Pagan test accepts the null hypothesis for models 2,3,4,5,9,10 whereas for models $1,6,7,8,11$, the test detects heteroskedasticity problems ( $p$-values are less than 5\%).The intra-individual autocorrelation test by Wooldrigde (2002) spots an autocorrelation problem for models $2,5,7,8,9,11$, and no serial autocorrelation for models $1,3,4,6,10$.

Eventually, the Panel of models 4 and 10 are evaluated by pooled OLS regression. The Panel models 3,2,5,9 are homoscedastic and uncorrelated, and are estimated by fixed effects / random effects with an autocorrelation correction if necessary for models 2,5 and 9. Models 1 and 6 are characterized by the presence of a heteroskedasticity problem and lack of autocorrelation. We use the model of random effects in order to correct the heteroskedasticity problem, and to correct the standard deviations by the Eicker-White method with the "robust" option. Models 7,8 and 11 present a problem of heteroscedasticity and autocorrelation of the residues. In this regression, the method of clustered standard errors is applied for correcting standard deviations of heteroscedasticity and autocorrelation.

\section{RESULTS AND DISCUSSIONS}

With the intention of testing the research hypothesis, multiple regression analysis is performed, and the outcomes are displayed in table 2 . In model 1 , the study estimates the effect of financial innovation on the bank performance to assess $\mathrm{H} 1$. The regression analysis in model 1 provides different results across the samples. The overall quality of the model is significantly acceptable. However, the findings show that there is a non-significant relationship between financial innovation and ROE while there is a positive relationship between financial innovation and MTB $(B=1.48, p<0.01)$. The first hypothesis applying that financial innovation positively influences the MTB is supported. These findings confirm the previous studies such as of Mabrouk and Mamoghli (2010), Xiangying, Yueyan and Xianhua (2015) and Aayale (2017). The positive effect thus found reinforces the assertions of Mustapha (2018) that investment in innovation enhances bank performance. However, there is no impact of financial innovation on ROE. These outcomes are inconsistent with prior results (De Young, Lang \& Nolle, 2007; Mabrouk \& Mamoghli, 2010; Chipeta \& Muthinja, 2018). 
In model 2, the study estimates the effect of financial innovation on risk management to evaluate $\mathrm{H} 2$. The overall quality of model 2 is significantly acceptable (chi2 $=43.10, \mathrm{~F}=2.52$, chi2 $=252.59,-\mathrm{p}<1 \%$ ), but the F-statistic is insignificant for the credit risk management variable $(\mathrm{F}=2.52, \mathrm{p}>10 \%)$.

In condition 2, the analysis records negative and significant beta coefficients across CAR and ORW, which is not verified for credit risk management. As a matter of fact, this result partially validates $\mathrm{H} 2$, and confirms the findings in the previous empirical research stating that innovation influences risk management (Philippas \& Siriopoulos, 2009; Mabrouk et al., 2016; Zia et al., 2019).

Our research seeks to assess the mediating impact of risk management on the relationship between financial innovation and bank performance in $\mathrm{H} 2$ and H3. The overall quality of models 3,4 and 5 is significantly acceptable, but only for model 3, the relationship between risk management and bank performance is insignificant $(\mathrm{t}=0.701, \mathrm{t}=0.45, \mathrm{p}>10 \%)$. At the detailed level, the impact of risk management on bank performance shows a positive relationship between financial risk management and bank performance. The findings provide evidence that the assertion made by Fatemi and Fooladi (2006), Hosna et al. (2009), Toutou and Xiaodong (2011), Zeze (2012), Trofimov et al. (2018) and Zgarni and Hassouna (2018) sets out that risk management improves the bank performance. Similarly, the research of Kiambati (2020) and Sathyamoorthi et al. (2020) demonstrated that there is a relationship between credit risk and shareholder market value among the commercial banks.

But there is an insignificant relationship between CAR and bank performance, these results are consistent with the findings of Mendoza and Rivera (2017) who found that capital adequacy has no significant effect of bank profitability while, they findings contradict the empirical studies of Wang (2014) and Lotto (2019).

Considering the fact that the first and the second conditions are met, the study performs the mediating effect in models 3,4 and 5. If a non-significant coefficient is found for the dependent variable (bank performance) as the mediator (risk management) is introduced into the equation, full mediation will occur. If the coefficient of the dependent variable remains significant in the presence of the mediator variable in models 3,4 and 5 , partial mediation will take place. Models 3 and 4 test the mediating effect of credit risk management, and total risk management shows there is a direct relationship between financial innovation and MTB, but a lack of relationship between financial innovation and ROE. Model 5 assesses the mediating impact of operational risk 
management, and proves that operational risk management partially mediates the relationship between financial innovation and stock market performance. However, there is no effect with the ROE. These results are consistent with the findings of Guermazi (2017) who finds out that risk management mediates innovation, and service quality of banks and insurance.

Our paper has shown and corroborated that the more the bank innovates, the greater it improves its market value. Moreover, the research in the banking sector is usually interested in financial risk even though the operational risk is becoming relevant in an uncertain environment. Our article accounts for the impact of operational risk management on market performance, which relates to the credibility of information and the reputation of banks.

Banks in Tunisia should focus more attention on capacity building and special training of bank managers whose function relate to financial innovations, credit and loans to serve as a conduit of giving them sufficient knowledge on how to deal with innovation issues and mitigate risks faced by these banks in order to improve their performance.

In addition, banks should do more efforts for contribute to revitalize the growth of the economy by investing in research and development and managing risks effectively in order to increase the performance.

\section{CONCLUSIONS}

Our paper reports the results of an empirical model including financial innovation, risk management and bank performance of 10 Tunisian listed commercial banks. A theoretical framework has been empirically tested, and the main purpose of our study is to investigate the mediating role of risk management between financial innovation and bank performance.

Our findings support the four hypotheses specified, and indicate a significant implication for the theory and empirical research. The initial hypothesis confirms a positive and significant relationship between financial innovation and market performance. On the other hand, the result shows there is a non-significant relationship between financial innovation and financial performance, which contradicts previous empirical research. In hypothesis 2 , there is a positive and significant relationship between Financial innovation, operational risk management and capital adequacy ratio. We also find a non-significant relationship between financial innovation and credit risk management. In hypoth- 
esis 3, we prove that the relationship is positive and significant between operational risk management and bank performance as well as between credit risk management and financial performance. This hypothesis is not supported for global risk management. In hypothesis 4 , we have provided evidence that there is a partial mediating effect of operational risk management between financial innovation and bank performance. In addition, we also find out an indirect relationship between financial innovation and market performance through credit risk management.

The findings of the study are significant as Tunisian commercial banks will understand the effectiveness of various risk management strategies (especially, innovation) and may apply them for minimizing risks incurred and enhance their market competitiveness.

Like any other research, this study has some limitations, and presents some new opportunities for future studies. Our findings can be generalized to other countries. Future studies may seek an alternative dataset such as a survey, can use an analysis method like a structural equation modeling and might apply our research in Islamic banks. Eventually, a theoretical model can also be extended by integrating a different typology of financial innovation such as product innovation, process innovation and organizational innovation. 


\begin{tabular}{|c|c|c|c|c|c|c|c|c|c|c|c|c|}
\hline \multirow{6}{*}{ 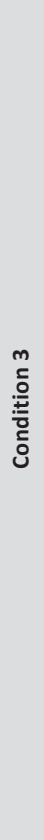 } & \multirow{2}{*}{ 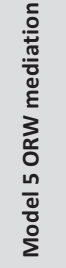 } & $\stackrel{\infty}{\Sigma}$ & 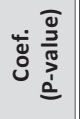 & 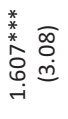 & & ' & 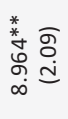 & 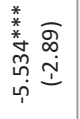 & 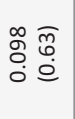 & $\begin{array}{l}\hat{i} \\
\hat{\sigma} \\
\dot{0} \\
\dot{0}\end{array}$ & 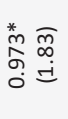 & \\
\hline & & 岁 & 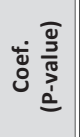 & 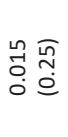 & & ' & 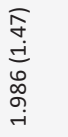 & 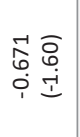 & 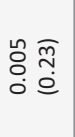 & 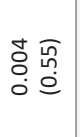 & 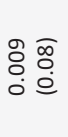 & $\begin{array}{l}\stackrel{*}{*} \\
\stackrel{*}{m} \\
\stackrel{\infty}{\infty}\end{array}$ \\
\hline & \multirow{2}{*}{ 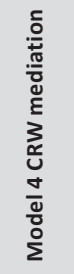 } & $\stackrel{\varrho}{\Sigma}$ & 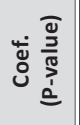 & 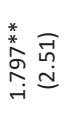 & ' & 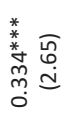 & ' & 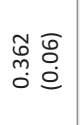 & 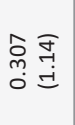 & 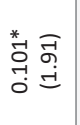 & 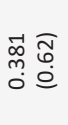 & \\
\hline & & 岁 & 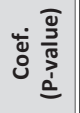 & 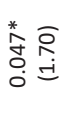 & I & 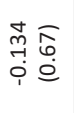 & ' & 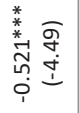 & 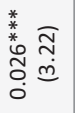 & 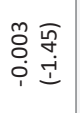 & 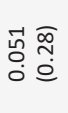 & \\
\hline & 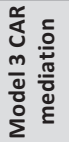 & $\stackrel{\mathscr{\rho}}{\Sigma}$ & 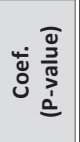 & 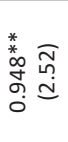 & 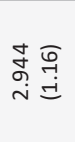 & ' & ' & 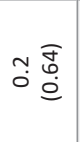 & 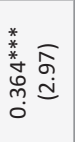 & 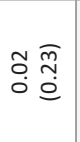 & 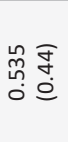 & \\
\hline & & 岁 & 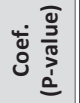 & 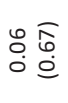 & 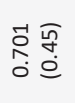 & ' & ' & 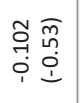 & 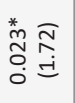 & 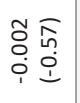 & 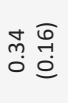 & \\
\hline \multirow{2}{*}{ 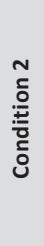 } & \multirow{2}{*}{ 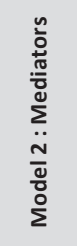 } & 疋 & 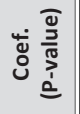 & 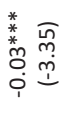 & ' & ' & ' & 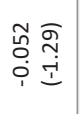 & 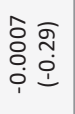 & 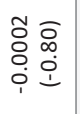 & 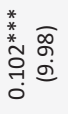 & \\
\hline & & בె & 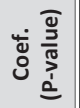 & 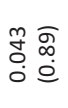 & ' & ' & ' & 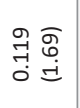 & 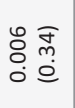 & 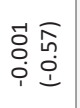 & 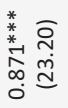 & $\stackrel{*}{\sim}$ \\
\hline \multirow{3}{*}{ 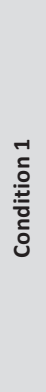 } & \multirow{3}{*}{ 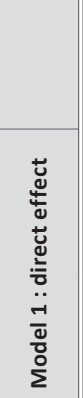 } & $\frac{\mathscr{\alpha}}{\overleftarrow{S}}$ & 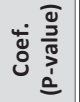 & 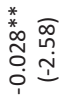 & 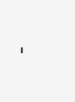 & ' & ' & 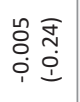 & 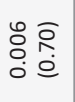 & 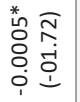 & 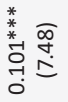 & \\
\hline & & $\stackrel{\mathscr{p}}{\Sigma}$ & 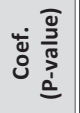 & 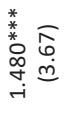 & 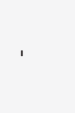 & ' & ' & 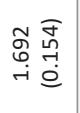 & \begin{tabular}{l}
$\underset{\infty}{\infty} \underset{\sim}{\mathbb{N}}$ \\
\hdashline \\
\hdashline
\end{tabular} & 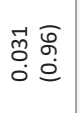 & 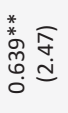 & $\begin{array}{l}\stackrel{*}{*} \\
\stackrel{*}{0} \\
\dot{n}\end{array}$ \\
\hline & & 岁 & 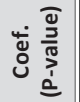 & 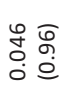 & ' & ' & ' & 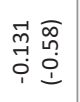 & 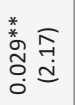 & 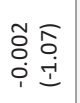 & 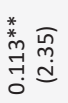 & \\
\hline \multicolumn{4}{|c|}{$\begin{array}{l}\frac{y}{0} \\
\frac{0}{0} \\
\frac{0}{2} \\
\frac{\pi}{5}\end{array}$} & 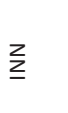 & 峁 & 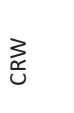 & $\sum_{\substack{0 \\
0}}^{3}$ & $\overline{\bar{n}}$ & 哟 & 岁 & 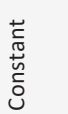 & 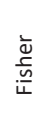 \\
\hline
\end{tabular}


FINANCIAL INNOVATION, RISK MANAGEMENT, AND BANK PERFORMANCE

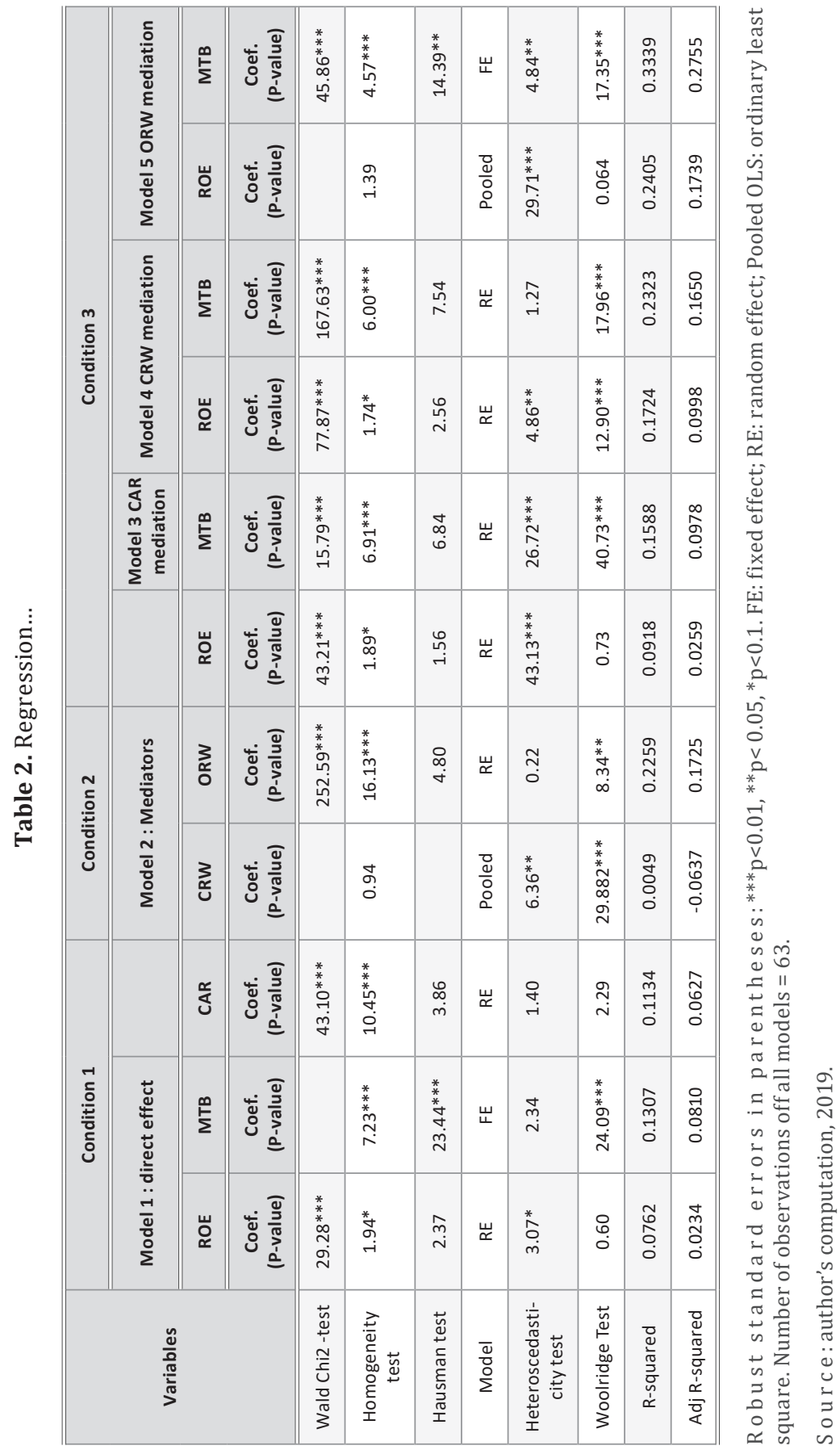




\section{REFERENCES}

Aayale, J. (2017). The impact of financial innovations on the financial industry's performance: a study of BRICS and G6 nations. International Journal of Economics, Commerce and Management, 7(11), 138-152.

Arnaboldi, F., \& Rossignoli, B. (2015). Financial innovation in banking. In E. Beccalli, F. Poli (Eds.). Bank Risk, Governance and Regulation. Palgrave Macmillan Studies in Banking and Financial Institutions. London: Palgrave Macmillan. https://dx.doi. org/10.1057/9781137530943_5.

Arthur, K.N.A (2017). The Emerging financial innovation and its governance: a historical literature review. Journal of Innovation Management, 5(4), 48-73. https://dx.doi. org/10.24840/2183-0606_005.004_0005.

Asensio-López, D., Cabeza-García, L., \& González-Álvarez, N. (2019). Corporate governance and innovation: a theoretical review. European Journal of Management and Business Economics, 28(3), 266-284. https://dx.doi.org/10.1108/EJMBE-05-2018-0056.

Baiquan, S., \& Kebao, W. (2010). Managing the Risks of Financial Innovations in Banking. In 2010 International Conference on Management and Service Science. Wuhan: Institute of Electrical and Electronics Engineers. https://dx.doi.org/10.1109/ICMSS.2010.5577186.

Baron, R.M., \& Kenny, D.A. (1986). The moderator-mediator variable distinction in social psychological research: Conceptual, strategic and statistical considerations. Journal of Personality and Social Psychology, 51(6), 1173-1182. https://dx.doi. org/10.1037//0022-3514.51.6.1173.

Battaglia, F., Fiordelisi, F., \& Ricci, O. (2017). Enterprise Risk Management and Bank Performance: Evidence from Eastern Europe during the Financial Crisis. In S. Boubaker (Ed.). Risk Management in Emerging Markets, Issues, Framework, and Modeling. Bingley: Emerald Group Publishing Limited.

Beck, T., Chen, T., Lin, C., \& Song, F.M. (2016). Financial innovation: The bright and the dark sides. Journal of Banking and Finance, 72, 25-51. https://dx.doi.org/10.1016/j. jbankfin.2016.06.012.

Chen, T.H., \& Peng, J.L. (2019). Statistical and bibliometric analysis of financial innovation. Library Hi Tech, Vol. ahead-of-print No. ahead-of-print. https://dx.doi. org/10.1108/LHT-09-2018-0140.

Chipeta, C., \& Muthinja, M. (2018). Financial innovations and bank performance in Kenya: Evidence from branchless banking models. South African Journal of Economic and Management Sciences, 21(1), 1-11. http://dx.doi.org/10.4102/sajems.v21i1.1681.

Ciciretti, R., Hasan, I., \& Zazzara, C. (2009). Do Internet Activities Add Value? Evidence from the Traditional Banks. Journal of Financial Services Research, 35(1), 81-98. https://dx.doi.org/10.1007/s10693-008-0039-2.

COSO - Executive Summary (2004). Enterprise Risk Management — Integrated Framework, New York, 3, 1-16. https://www.coso.org/Documents/COSO-ERM-ExecutiveSummary.pdf. 
De Young, R., Lang, W.W., \& Nolle, D.L. (2007). How the Internet affects output and performance at community banks. Journal of Banking and Finance, 31(4), 1033-1060. https://dx.doi.org/10.1016/j.jbankfin.2006.10.003.

El Attar, A., \& Atmani, M. (2015). La gestion des risques des produits financiers islamiques: essai de modélisation. Dossiers de Recherches en Economie et Gestion, 2(4), 2-29. http://dx.doi.org/10.12816/0030990.

European Central Bank (2010). Beyond roe - how to measure bank performance, European Central Bank, Appendix to the report on EU banking structures, https:// www.ecb.europa.eu/pub/pdf/other/beyondroehow tomeasurebankperformance 201009en.pdf.

Fatemi, A., \& Fooladi, I. (2006). Credit Risk Management: A Survey of Practices. Managerial Finance, 32(3), 227-233. https://dx.doi.org/10.1108/03074350610646735.

Frame, W.S., \& White, L.J. (2002). Empirical Studies of Financial Innovation: Lots of talk, Little Action. FRB of Atlanta Working Paper, 2002-12. http://dx.doi.org/10.2139/ ssrn.325800.

González, L.O., Rodríguez Gil, L.I., Cunill, O.M., \& Lindahl, J.M. (2016). The effect of financial innovation on European banks' risk. Journal of Business Research, 69(11), 4781-4786. https://dx.doi.org/10.1016/j.jbusres.2016.04.030.

Guermazi, H.H. (2017). Effet médiateur de la gestion de risque et du style de direction sur la relation Innovation - Qualité du service: étude des assurances et des banques en Tunisie. Revue Questions de Management, 18(3), 113-124. https://dx.doi. org/10.3917/qdm.173.0113.

Halim, E.H., Mustika, G., Sari, R.N., Anugerah, R., \& Mohd-Sanusi, Z. (2017). Corporate governance practices and financial performance: The mediating effect of risk management committee at manufacturing firms. Journal of International Studies, 10(4), 272-289. http://dx.doi.org/10.14254/2071-8330.2017/10-4/21.

Heffernan, S., Fu, X., \& Fu, M. (2008). Financial Innovation in the UK. Faculty of Finance Working Paper, 4. http://dx.doi.org/10.2139/ssrn.1266125.

Hosna, A., Manzura, B., \& Juanjuan, S. (2009). Credit Risk Management and Profitability in Commercial Banks in Sweden. Gothenburg: University of Gothenburg.

Hu, D.-L., Li J.-Q., \& Deng, Y.H. (2009). Notice of Retraction: Insighting the Risk Management of Financial Innovation from the Viewpoint of Subprime Mortgage Crisis. In International Conference on Management and Service Science Wuhan: Institute of Electrical and Electronics Engineers. http://dx.doi.org/10.1109/ICMSS.2009.5301359.

$\mathrm{Hu}, \mathrm{T} .$, \& Xie, C. (2016). Competition, Innovation, Risk-Taking, and Profitability in the Chinese Banking Sector: An Empirical Analysis Based on Structural Equation Modeling. Discrete Dynamics in Nature and Society. 6, 1-10. http://dx.doi. org/10.1155/2016/3695379.

Jordan, S., Jorgensen, L., \& Mitterhoferh, H. (2013). Performing risk and the project: Risk maps as mediating instruments. Management Accounting Research, 24(2), 156-174. https://dx.doi.org/10.1016/j.mar.2013.04.009.

Khraisha, T., \& Arthur, K. (2018). Can we have a general theory of financial innovation processes? A conceptual review. Financial Innovation, 4(4), 1-27. https://dx.doi. org/10.1186/s40854-018-0088-y. 
Kiambati, K. (2020). Influence of credit risk on shareholder market value of commercial banks listed in Nairobi Securities Exchange. International Journal of Research in Business and Social Science (2147-4478), 9(2), 107-117. http://dx.doi.org/10.20525/ ijrbs.v9i2.613.

Lerner, J., \& Tufano, P. (2011). The Consequences of Financial Innovation: A Counterfactual Research Agenda. Annual Review of Financial Economics, 3(1), 41-85. https:// dx.doi.org/10.1146/annurev.financial.050808.114326.

Llewellyn, D.T. (2009). Financial Innovation and the Economics of Banking and the Financial System. In L. Anderloni, D.T. Llewellyn, R.H. Schmidt (Eds.). Financial Innovation in Retail and Corporate Banking. Cheltenham: Edward Elgar Publishing. https:// doi.org/10.4337/9781848447189.00007.

Lotto, J. (2019). Evaluation of factors influencing bank operating efficiency in Tanzanian banking sector. Cogent Economics \& Finance, 7(1). https://dx.doi.org/10.1080/23 322039.2019 .1664192$.

Mabrouk, A., \& Mamoghli, C. (2010). Dynamic of financial innovation and performance of banking firms: context of an emerging banking industry. International research Journal of Finance and Economics, 51, 17-36.

Mabrouk, A., Dhouibi, R., \& Rouetbi, E. (2016). Interaction effect between product and process innovation: the case of Tunisian banks. Banks and Bank Systems, 11(1), 60-70. http://dx.doi.org/10.21511/bbs.11(1).2016.07.

Malhotra, P., \& Singh, B. (2009). The Impact of Internet Banking on Bank Performance and Risk: The Indian Experience. Eurasian Journal of Business and Economics, 2(4), 43-62.

McShane, M.K., Nair, A., \& Rustambekov, E. (2011). Does Enterprise Risk Management Increase Firm Value. Journal of Accounting, Auditing \& Finance, 26(4), 641-658. https://dx.doi.org/10.1177/0148558X11409160.

Mendoza, R., \& Rivera, J.P.R. (2017). The effect of credit risk and capital adequacy on the profitability of rural banks in the Philippines. Scientific Annals of Economics and Business, 64(1), 83-96. https://dx.doi.org/ 10.1515/saeb-2017-0006.

Merton, R.C. (1992). Financial Innovation and Economic Performance. Journal of Applied Corporate Finance, 4(4), 12-22. https://dx.doi.org/10.1111/j.1745-6622.1992. tb00214.x.

Minetti, R., Murro, P., \& Paiella, M. (2015). Ownership Structure, Governance and Innovation. European Economic Review, 80(C), 165-193. https://dx.doi.org/10.1016/j.euroecorev.2015.09.007.

Mustapha, S.A. (2018). E-Payment technology effect on bank performance in emerging economies-evidence from Nigeria. Journal of Open Innovation: Technology, Market, and Complexity, 4(4), 43. https://dx.doi.org/10.3390/joitmc4040043.

Nejad, M.G. (2016). Research on Financial Services Innovations: A Quantitative Review and Future Research Directions. International Journal of Bank Marketing, 34(7), 1042-1068. http://dx.doi.org/10.1108/IJBM-08-2015-0129.

OECD (2005). Oslo Manual: Guidelines for Collecting and Interpreting Innovation Data. 3rd Edition. Paris: OECD Publishing. https://www.oecd-ilibrary.org/docserver/9789 
264013100-en.pdf?expires $=1587684547 \& \mathrm{id}=\mathrm{id} \&$ accname=guest\&checksum $=53 \mathrm{DB}$ 6ACD0B7BAECC6A8C10FB54DEFC19.

Olamide, O., Uwalomwa, U., \& Ranti, U.O (2015). The Effect of Risk Management on Bank's Financial Performance in Nigeria. Journal of Accounting and Auditing: Research \& Practice, 2015, 1-7. https://dx.doi.org/10.5171/2015.239854.

Paroush, J., \& Schreiber, B.-Z. (2019). Profitability, capital, and risk in US commercial and savings banks: Re-examination of estimation methods. The Quarterly Review of Economics and Finance, 74(C), 148-162. https://dx.doi.org/10.1016/j.qref.2018.12.007.

Philippas, D.T., \& Siriopoulos, C. (2009). Influence of financial innovation to the validation of operational risk. Managerial Finance, 35(11), 940-947. https://dx.doi. org/10.2139/ssrn.1851633.

Piyananda, S.D.P, Chandrasena, S.M., \& Fernando, J.M (2015). Bank-Specific Determinants of Risk Management Efficiency: Evidence from Listed Commercial Banks in Sri Lanka. In 6th International Conference on Business and Information (ICBI). Sri Lanka: Faculty of Commerce and Management Studies, University of Kelaniya, 78-89. https://pdfs.semanticscholar.org/ec76/285d5c88496b014dfe466c614d493bcdb866. pdf?_ga=2.266247759.1732821706.1587683938-52817079.1587683938.

Sathyamoorthi, C.R., Mogotsinyana, M., Mphoeng, M., \& Mashoko, D. (2020). Impact of Financial Risk Management Practices on Financial Performance: Evidence from Commercial Banks in Botswana. Applied Finance and Accounting, 6(1), 25-39. https://dx.doi.org/10.11114/afa.v6i1.4650.

Sokołowska, E. (2014). Alternative Investments in Wealth Management. Switzerland: Springer. http://dx.doi.org/10.1007/978-3-319-08075-8.

Stone, A., Shipp, S., \& Leader, P. (2008). Measuring Innovation and Intangibles: A Business Perspective. Washington: Science \& Technology Policy Institute. IDA Document D-3704. https://www.ida.org/-/media/feature/publications/m/me/measuring-innovation-and-intangibles-a-business-perspective/ida-d-3704.ashx.

Stulz, R.M. (2016). Risk Management, Governance, Culture, and Risk Taking in Banks. Economic Policy Review, 22(1), 43-60.

Stulz, R.M., \& Smith, C.W. (1985). The Determinants of Firm's Hedging Policies. Journal of Financial and Quantitative Analysis, 20(4), 391-406. https://dx.doi.org/10.2307/ 2330757.

Toutou, J., \& Xiaodong X. (2011). The Relationship between Liquidity Risk and Performance, an Empirical Study of Banks in Europe 2005-2010. Umeå: Umea School of Business. https://urn.kb.se/resolve?urn=urn\%3Anbn\%3Ase\%3Aumu\%3Adiva-54456.

Trofimov, I.D., Aris, N.M., \& Ying Ying, J.K. (2018). Determinants of commercial banks' profitability in Malaysia. Management and Economics Review, 3(1), 85-101. http:// dx.doi.org/10.24818/mer/2018.06-07.

Tufano, P. (2003). Financial Innovation. In G.M. Constantinides, M. Harris, R.M. Stulz (Eds.). Handbook of the Economics of Finance. Amsterdam: Elsevier. https://dx.doi. org/10.1016/S1574-0102(03)01010-0.

Tunay, K.B., Tunay, N., \& Akhisar, I. (2015). The Effects of Innovations on Bank Performance: The Case of Electronic Banking Services. Procedia - Social and Behavioral Sciences, 195, 369-375. https://dx.doi.org/10.1016/j.sbspro.2015.06.336. 
Usman, M. (2016). Bank Performance, Risk and Economic Growth: Role of Financial Innovation. Journal on Innovation and Sustainability, 7(3), 3-16. https://dx.doi. org/10.24212/2179-3565.2016v7i3p3-22.

Wang, M.S. (2014). Financial Innovation, Basel Accord III, and Bank Value. Emerging Markets Finance and Trade, 50(2), 23-42. https://dx.doi.org/10.2753/REE1540496X5002S202.

Wanjohi, S.M., Wanjohi, J.G., \& Ndambiri, J.M. (2017). The Effect of Financial Risk Management on the Financial Performance of Commercial Banks in Kenya. International Journal of Finance and Banking Research, 3(5), 70-81. http://dx.doi.org/10.11648/j. ijfbr.20170305.

Williamson, O.E. (1985). The Economic Institutions of Capitalism: Firms, Markets and Vertical Contracting. New York: Free Press. Traduction française, Les institutions de l'économie, 1994, InetrEditions.

Xiangying, M., Yueyan, Z., \& Xianhua, W.E.I. (2015). Market value of Innovation: An empirical analysis on China's stock market. Procedia Computer Science, 55, 1275-1284. https://dx.doi.org/10.1016/j.procs.2015.07.138.

Zeze, O.S. (2012). The Relationship between Credit Risk Management Practices and Financial Performance of Commercial Banks in Liberia. MBA Unpublished Research Project. Nairobi: University of Nairobi. http://erepository.uonbi.ac.ke/handle/11295/13262.

Zgarni, A., \& Hassouna, F. (2018). Regulation and Bank Performance. The Journal of American Business Review, 6(2), 15-22.

Zia, U.-R., Muhammad, N., Sarwar, B., \& Asif Raz, M. (2019). Impact of risk management strategies on the credit risk faced by commercial banks of Balochistan. Financial Innovation, 5(44), 1-13. https://dx.doi.org/10.1186/s40854-019-0159-8.

Zouari, G., \& Zouari-Hadiji, R. (2014a). Directors' Board, R\&D Investment and the Firm's Performance: Evidence from the French Case. Corporate Board: Role, Duties \& Composition, 10(2), 85-101. http://dx.doi.org/10.22495/cbv10i2art7.

Zouari, G., \& Zouari-Hadiji, R. (2014b). The Indirect Impact of the Board of Directors' Composition on the Firm's Performance: An International Comparison. Asian Journal of Empirical Research, 4(10), 468-487. 